\title{
Plant Genetic Resources and Scientific Activities of the Uzbek Research Institute of Plant Industry
}

\author{
Ravza F. Mavlyanova, Faizulla Kh. Abdullaev, and Payzillo Khodjiev \\ Uzbek Research Institute of Plant Industry, 702133, P.O. Botanika, Kibray District, Tashkent Province, Uzbekistan
}

David E. Zaurov, Thomas J. Molnar, Joseph C. Goffreda, Thomas J. Orton, ${ }^{1}$ and C. Reed Funk

Department of Plant Biology \& Pathology, Cook College, Rutgers University, 59 Dudley Road, New Brunswick, NJ 08901-8520

Additional index words. germplasm collection, breeding, cotton, cereal, fruit, melon, vegetable

The Uzbek Research Institute of Plant Industry, located in Tashkent Province of the Republic of Uzbekistan, was established in 1924 by the renowned Russian plant collector and geneticist Nikolai I. Vavilov (1887-1943). As director of the extensive Leningrad Institute of Applied Botany, Plant Genetics, and Breeding, Vavilov recognized that Central Asia was an important center of origin of many crop species and subsequently developed the Central Asian Branch of the institute. Since then, Academician Nikolai I. Vavilov, Konstantin I. Pangalo, Galina M. Popova, Pavel A. Baranov, Alexander M. Negrul, Yakov F. Katc, Klavdiya F. Kostina, Nikolai V. Kovalev, and many others have organized an expansive worldwide collection of tree fruits, grapes (Vitis vinifera L.), melons (Cucumis melo L.), vegetables, forage, and fiber crops at the institute. In addition to germplasm collection, the institute has conducted evaluations, breeding, and research of wheat (Triticum spp.), cotton (Gossypium spp.), maize (Zea mays L.), melons, and grapes, as well as other promising food, forage, and fiber crops.

The main goals of the early institute were the collection and storage of seeds, the evaluation of plant genetic resources from around the world under the various climatic zones of Uzbekistan (Fig. 1), the organization of seed production, and the development of improved agricultural practices for the region. In the 1970s, under the leadership of Academician Mirza Ali V. Mukhamedjanov, the institute's role within the academic system of the former Soviet Union was expanded. The institute's scientists trained graduate students that went on to earn advanced degrees from recognized research institutes and universities within Uzbekistan and other Commonwealth of Independent States countries. Since the institute was organized, eighty-five graduate students successfully defended $\mathrm{PhD}$ dissertations and were granted degrees in the field of plant breeding and genetic resources. While serving as director, Mukhamedjanov also made many important contributions to the genetic resource holdings of the institute and

Received for publication 28 July 2004. Accepted for publication 6 Aug. 2004. Contact:Ravza F. Mavlyanova (Research Director), Uzbek Research Institute of Plant Industry, 702133, P.O. Botanika, Kibray District, Tashkent Province, Uzbekistan; phone 998712-64-23-74; fax 998712-39-49-93.

${ }^{1}$ Department of Extension Specialists, Rutgers Cooperative Extension, Rutgers University, New Brunswick, NJ 08901-8520. breeding programs flourished during his time.

In 1992 the institute was renamed to its current title, the Uzbek Research Institute of Plant Industry (UzRIPI), after Uzbekistan became an independent country (see Table 1 for a chronology of the institute's names). At present, UzRIPI occupies 140 ha of arable land, including 74 ha of orchards with the remainder used for grain, melon, and vegetable crop research. UzRIPI also oversees experiment stations in Andijon (Farghona Valley) and Surkhondaryo provinces where they conduct evaluations of cultivars and other plant populations under different climatic conditions (Fig. 1). UzRIPI houses the following departments and support laboratories: Plant Introduction; Field Crops; Industrial Crops; Vegetables, Melons, and Potatoes (Solanum tuberosum L.); Fruits, Berries, and Grapes; Biochemistry; Seed Biology; and Plant Germplasm Resources Database Management.
Currently, the main goals of the institute are to 1 ) enrich the existing germplasm holdings by executing collection expeditions of endangered, cultivated, and wild plant species; 2) maintain the longevity of the existing collection by seed viability testing and periodic seed increases; 3 ) develop and implement strategies for mid- and long-term storage of plant germplasm; 4) undergo reciprocal exchange of plant germplasm with research institutes, germplasm repositories, and government agencies worldwide; 5) successfully quarantine seeds and clonal materials undergoing testing for infestation with potentially threatening agents; 6) efficiently and effectively evaluate germplasm to identify and further test accessions showing agricultural promise; 7) develop and maintain a database of all accessions that includes key descriptors, such as collection site and performance parameters along with preliminary recommendations to

Table 1. Chronology of the names of Uzbek Research Institute of Plant Industry (UzRIPI).

\begin{tabular}{lc}
\hline Name of institute & Years \\
\hline Central Asian Branch of the Saint Petersburg (Leningrad) Institute of Applied Botany & $1924-1927$ \\
Central Asian Experiment Station of the All-Union Research Institute of Plant Industry & $1927-1979$ \\
Central Asian Branch of the All-Union Vavilov Institute of Plant Industry (referred to as VIR) & $1979-1991$ \\
Uzbek Research Institute of Plant Industry & $1992-$ present \\
\hline
\end{tabular}

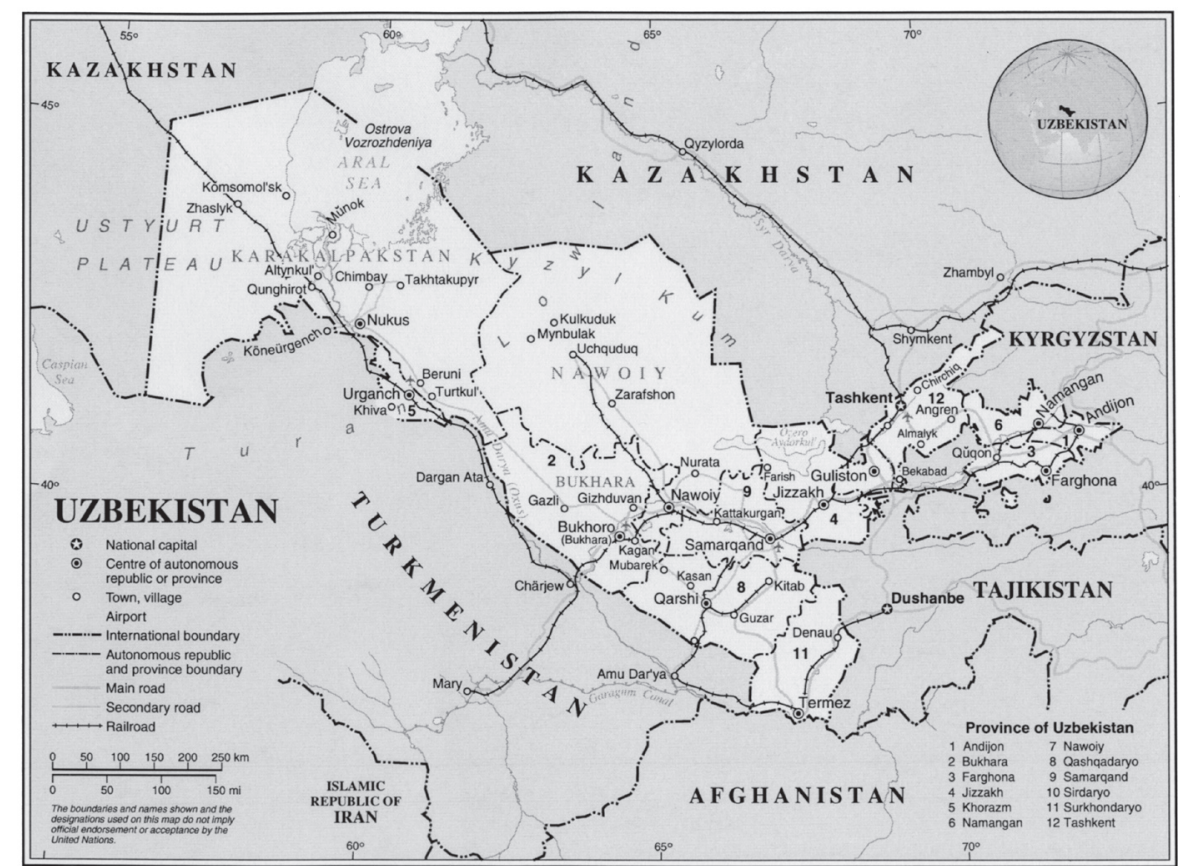

Fig. 1. Map of the Republic of Uzbekistan (reproduced with permission from the Dept. of Public Information, Cartographic Section, United Nations, Map no. 3777 Rev. 5, August 2003). 
breeders and geneticists; and 8) produce seed of strains showing high promise for breeders, geneticists, and farmers.

Germplasm resources. UzRIPI maintains over 50,000 accessions of 210 plant species from 98 countries, including economically valuable agricultural crops and wild relatives. The collection consists of the following numbers of accessions: 16,000 cereals; 1,600 legumes; 9,200 oil and fiber crops; 1,500 forages; 5,000 vegetables and melons; over 4,000 tree fruits, berries and grapes; and 140 medicinal and other nontraditional crops. The institute maintains 6,300 live plant specimens in the greenhouse and field as well as numerous herbarium specimens. The entire germplasm collection is diligently maintained through the regeneration of viable seeds and clonal materials. Reciprocal germplasm exchange programs have been developed between UzRIPI and a number of institutions worldwide, including active collaborations with the All Union N. I. Vavilov Institute of Plant Industry in St. Petersburg and centers of the world Genebank (IPGRI, ICARDA, CIMMYT, ICRISAT, RDA, NIAR). Through these collaborations, improved cultivars of many crop species from around the world have been acquired and tested for adaptation to Central Asian growing conditions.

Operational activities. The U.S. Department of Agriculture provided funds to UzRIPI in late 2002 for the reconstruction of seed germplasm storage facilities. These improvements have been completed, and the institute now has the capability to store plant materials under optimum temperature and relative humidity conditions. UzRIPI maintains a comprehensive database of their germplasm holdings, which was recently converted from hard copy to computer-based. The database is modeled after the VIR, ICARDA, IPGRI, and USDA accession passport systems. The UzRIPI database system includes the following fields of information: plant resource introduction data, collection expedition data, passport data, taxonomy and accession descriptions, and more.

Before entering the collection, incoming seeds and clonal material are subjected to rigorous quarantine procedures. Quarantined plants are evaluated extensively for the presence of disease pathogens, insects, and other potentially threatening agents. UzRIPI examines about 2,000 quarantined incipient accessions annually. At the completion of this process, the quarantine unit recommends release to the collection or destruction of the plant materials under conditions that will eliminate the undesirable agent. UzRIPI has developed excellent facilities for the large-scale clonal propagation of woody perennial species such as tree fruits and grapes, and is also responsible for the production of seed and its distribution to growers.

Research and collection expeditions. The institute's scientists have been continually evaluating existing and new accessions for potential scientific and economic value. Accessions are being evaluated in diverse geographical/climatic regions within Central Asia to determine their performance and usefulness. Geneticists have also been studying the inheritance of characteristics such as disease and insect resistance, tolerance to environmental extremes, and lack of lodging in cereal crops.

Physiological research on the affects of environmental stresses such as soil salinity, drought, and heat have been performed on cereals, legumes, and other crops. Species studied include Triticum sp., maize, sorghum [Sorghum bicolor (L.) Moench], barley (Hordeum vulgare L.), chickpeas (Cicerarietinum L.), mung bean (Phaseolus aureus Roxb.), tomato (Lycopersiconesculentum L.), cabbage (Brassica oleracea L.), and melons. Work has also been done to examine new specialty crops for production in Central Asia, such as Stevia rebaudiana (Bertoni), a source of natural sweetening compounds (Kim and Duseinov, 1994).

The effects on viability and germination of seeds stored in liquid nitrogen were investigated at the institute. These studies were conducted in collaboration with the All Union N. I. Vavilov Institute of Plant Industry in St. Petersburg, Russia during 1986 to 1990 involving carrot (Daucus carota L.), radish (Raphanus sativus L.), tomato, celery (Apium graveolens L.), dill (Anethum graveolens L.), turnip (Brassica rapa L.), beets (Beta vulgaris L.), eggplant (Solanum melongena L.), cabbage, wheat (Triticum aestivum L.), maize, sorghum, oats (Avena sativa L.), barley, soybean [Glycine $\max (\mathrm{L}$.) Merrill], and cowpea [Vigna unguiculata (L.) Walp.] (Zaitcev et al., 1993; Levkina, 1992).

The institute has planned and executed plant collection expeditions yearly since 1924 . Initially, expeditions were focused primarily in Central Asia, although N. I. Vavilov collected materials worldwide. Vavilov used these early collections in the formulation of his theory on the centers of origin of cultivated plants (Vavilov, 1926, 1951). More recently, the All Union N. I. Vavilov Institute of Plant Industry in St. Petersburg supported collection of germplasm in Russia, Yugoslavia, Bolivia, China, Korea, Vietnam, and other countries. These collections included modern cultivars in addition to more primitive selections and landraces, for use in the contemporary breeding programs. Unique lines of Prunus sp., Persian walnuts (Juglans regia L.), melons, legumes, vegetables, oilseed, and forage crops from Central Asia have recently been added to the institute's collection. From 1965 to 1990 , over 150 plant collection expeditions were conducted in Central Asia, resulting in 15,000 new accessions consisting mostly of wild relatives of economic plant species. Over 25,000 herbarium specimens were also collected (Tsangas, 1994).

Following the independence of Uzbekistan in 1991, the institute sponsored over 40 plant collection expeditions to Central Asia yielding 3,025 new accessions of economic plant species for their germplasm holdings. Expeditions in the Pamir Mountains brought back rye (Secale cereale $\mathrm{L}$.) lines that have large seeds and spikes and legumes and wild grasses from different elevations. Also from this region, the first known collections of Aegilops sp. (goat grass) were made and a new latex-bearing plant was introduced to the collection, Scorzonera tau-saghyz Lipsch. et Bosse., that promises to be a source of natural rubber. Further, new ecotypes of prostrate summer cypress [Kochia prostrata (L.) Schrad.] and saxaul (Haloxylon persicum Bunge.) were collected.

During the many collection expeditions, much information has been accumulated on the range of habitats and ecosystems where the target species occur. The institute's scientists studied the range in genetic diversity of 1,380 cultivars of 10 vegetable crop species growing in Uzbekistan, including carrot, radish (both globe and forcing), turnip, beet, lettuce (Lactuca sativa L.), dill, celery, parsley (Petroselinum crispum Mill.), and parsnip (Pastinaca sativa L.) (Mavlaynova et al., 1998). During the course of plant collecting since the 1920 s, scientists have noted that landraces and related wild species of economic crops have been steadily disappearing in Central Asia (Brejnev, 1974; Vavilov, 1926). Consequently, recent exploration efforts have focused on the collection of endangered endemic germplasm. These exploration efforts involved a consortium of Central Asian institutes in addition to UzRIPI, including the Richard R. Schroeder Uzbek Scientific Research Institute of Fruit Growing, Viticulture and Wine Production, the Uzbek Scientific Research Institute of Vegetable, Melon, and Potato, the Cotton Breeding and Seed Production Institute, the Uzbek Scientific Research Institute of Botany, and others. Key scientists involved in these collection efforts were Natalya I. Zaktreger, Roald A. Udachin, Klavdiya A. Kobilskaya, Eduard N. Lomakin, Nikolai G. Ruban, Tatyana N. Ulyanova, Vladislav I. Shichkov, Fotis T. Tsangas, Irshat Sh. Shahmedov, Aleksei F. Pimakhov, Karim I. Baimetov, and Z. P. Shutova (Tsangas, 1994). Collections were made over a broad range of environments and elevations in all countries of Central Asia.

Breeding. Breeding activities at the institute were started in the mid-1920s. Since then, over 750 cultivars have been released with 65 still in wide cultivation in Central Asia, including 20 that are under production in other regions. At present, UzRIPI is releasing new cultivars at the rate of 1 to 2 per year.

Grapes. Pavel A. Baranov, Ilariya A. Raikova, Yakov F. Katz, and Alexander M. Negrul were responsible for the collection, evaluation, and culture of grapes (Vitis vinifera) at the institute (Pugachev and Djabbarov, 1974). Simultaneous grape collection and evaluation was conducted in Tashkent province at the Richard R. SchroederUzbek Scientific Research Institute of Fruit Growing, Viticulture, and Wine Production with their collection containing 1,300 advanced accessions (Esenbaev et al., 1981).

At the institute over 100 grape selections have been collected that feature very large fruit with unique pigmentation and excellent quality. Parthenocarpic (seedless) types have also been found and added to the collection. In central Kopetdag and the Kizilha and Oktan gorges of Turkmenistan, andromonoecious grape selections were collected. Strong evidence supports the Kopetdag region of Turkmenistan as the center of origin of $V$. vinifera $L$. ssp. sylvestris Gmel. (Tsangas, 1994).

Basicinheritance studies have been conducted on various important economic characteristics of grapes including early maturity, sex expression, fruit size, seedlessness, and cluster density. 


\begin{tabular}{|c|c|c|c|c|c|c|c|c|}
\hline Cultivar & $\begin{array}{l}\text { Avg } \\
\text { fruit } \\
\text { wt } \\
(g)\end{array}$ & $\begin{array}{c}\text { Avg } \\
\text { cluster } \\
\text { wt } \\
(g)\end{array}$ & $\begin{array}{l}\text { Time } \\
\text { of } \\
\text { ripening }\end{array}$ & $\begin{array}{c}\text { Soluble } \\
\text { solids } \\
(\%)\end{array}$ & $\begin{array}{l}\text { Fruit } \\
\text { color }\end{array}$ & $\begin{array}{c}\text { Yield } \\
\left(\mathrm{t} \cdot \mathrm{ha}^{-1}\right)\end{array}$ & $\begin{array}{l}\text { Major } \\
\text { end } \\
\text { use }\end{array}$ & Seedless \\
\hline Tarnau & 1.8 & 520 & Mid-August & 22 & Yellow-green & $48-60$ & Wine & Yes \\
\hline Oktyabrskii & 5.9 & $400-500$ & October & 24 & Pink with thick wax & $36-40$ & Fresh & No \\
\hline Guzal kara & $6.4-6.8$ & $480-584$ & Mid- to end of August & 22 & Black with thick wax & $20-25$ & Fresh & No \\
\hline Kishmish VIRa & 2.1 & 360 & Mid-August & 26 & Green-yellow & $20-25$ & Fresh, dried & Yes \\
\hline Muskat Uzbekistana & 5.0 & 500 & Late- October & 25 & Green-yellow & $40-50$ & Fresh, wine & No \\
\hline Perlet $^{\mathrm{z}}$ & 1.95 & 416 & Mid-July & 26.6 & White-yellow & $28-32$ & Fresh, dried & Yes \\
\hline
\end{tabular}

${ }^{\mathrm{z}} \mathrm{US}$ check cultivar.

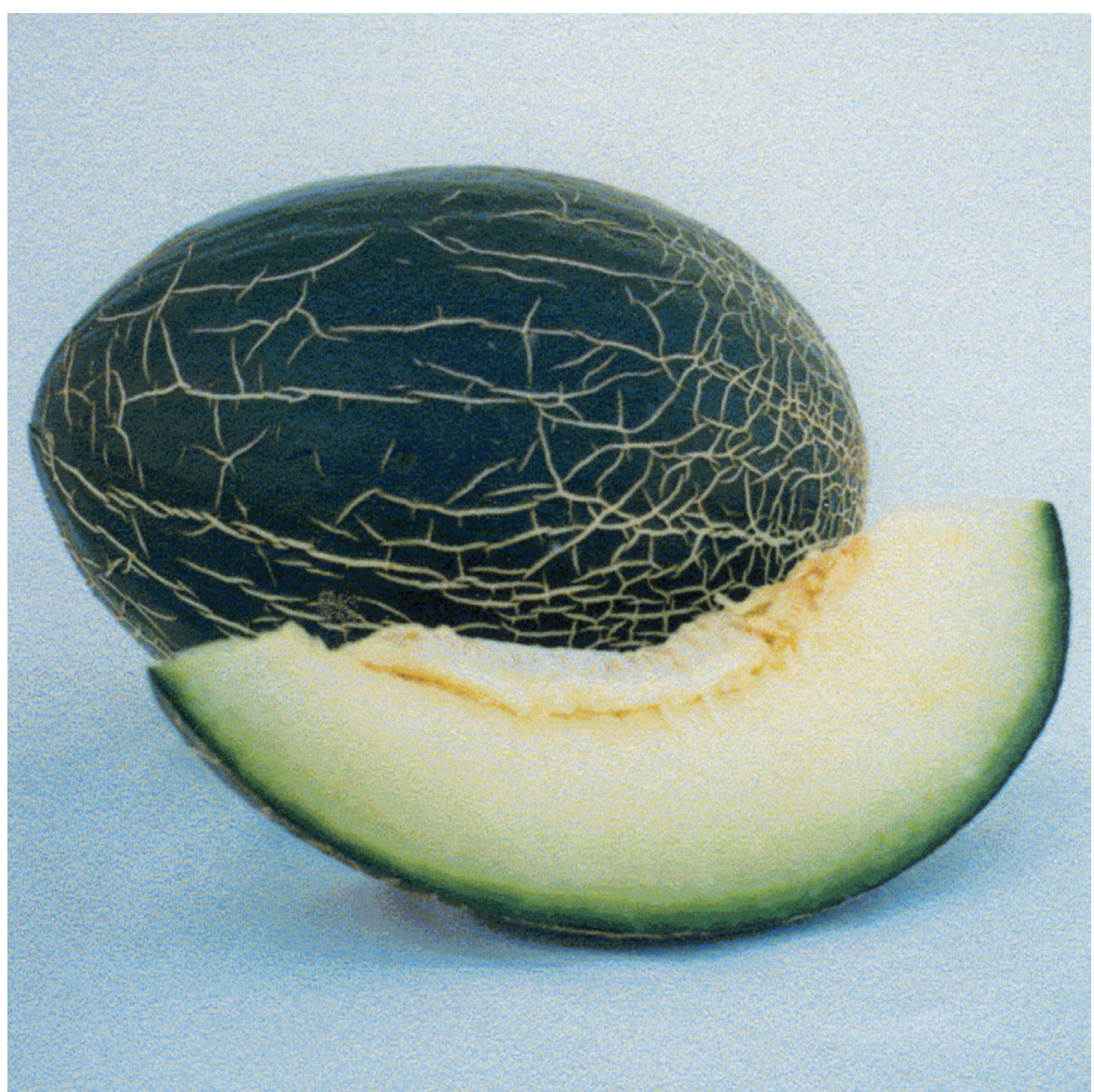

Fig. 2. Melon 'Umirvaki 3748'. Shelf life up to 7 months. Developed by K.I. Pangalo and M.K. Goldgauzen at the Uzbek Research Institute of Plant Industry.

These studies have incorporated germplasm from France ('Madlen Anjevin' used as female parent), Turkmenistan ('Kishmish Turkmensky' and 'Kara djidjigi' used as male parents), and Hungary ('Jemchug Saba' used as male parent) (Juravel and Ruban, 1968). NG. Ruban published a comprehensive description of grape cultivars grown in Central Asia in 1972.

Using the vast grape collection, many important grape cultivars were developed with many still very popular in Central Asia. These include a) table (fresh)-'Guzal kara', 'Volgo-Don', 'Pobeda', 'Muscat Uzbekistanskii', 'Oktaybrskii', 'Hurmani Kizil', 'Italiya', 'Karaburnu'; b) wine-'Tarnau', 'Muscat VIR', 'Superka'; and c) dried-'Ak-tash', 'Nilufar', 'Bessemaynnii', 'Kishmish rozovii', 'Kishmish VIR' (Table 2). A.M. Negrul and M.S. Juravel were presented with the most prestigious State Award in the former Soviet Union for achievements in grape breeding.
Cotton. The UzRIPI cotton collection currently consists of over 5,000 accessions from around the world representing Gossypium hirsutum L., G. barbadense L., G. arboreum L., and $G$. herbaceum L., including 70 tetraploid forms and 29 wild diploid forms. Collections of pima cotton ( $G$. barbadense) were made from growers fields and experiment stations within Central Asia that are early maturing, wilt (Verticillium dahliae Klebahn.) resistant and have up to $34 \%$ boll fiber content.

From the institute's cotton germplasm collection, scientists have selected lines that exhibit early maturity, high yield, high fiber content and quality, high seed oil and protein content, and absence of gossypol.Also, compact bush types have beenidentified that are adapted to higher planting densities and mechanical harvesting (Visotskii, 1968; Shahmedov and Lemeshv, 1987).

Intraspecific and interspecific hybridizations have been conducted among populations from diverse geographical regions within Central Asia. Among the major breeding advances is the development of improved cultivars with genetic resistance to Verticillium dahliae and spider mites (Tetranychus spp.). Wilt resistance genes were transferred from Gossypium hirsutum L. Ssp. mexicanum var. nervosum (Mauer) into the 'Tashkent-X' series of cultivars 'AN-Uzbekistan 3', 'Kzil Ravat', and 'Regar-1'. Interspecific crosses were made between tetraploid cultivated cotton species and diploid G. aridum (Rose \& Standl.), from which hexaploid progeny were selected that featured natural defoliation (Visotskii, 1968).

Many superior new cultivars have been selected from Gossypium hirsutum Acala populations. The North American cultivars 'Delfos', 'Coker', 'Columbia', and others were used in the breeding of the Central Asian cultivars '108F', 'C-450', 'C-460', and 'C-1819'. The U.S. cultivar 'Acala 4-42' was used in the breeding of the wilt resistant Central Asian cultivars ' $175-\mathrm{F}$ ', '2602', and '2606'. Today these cultivars are widely grown throughout Central Asia.

UzRIPI is also conducting cotton projects in collaboration with other Central Asian research institutions. Joint evaluation of cotton hybrids by UzRIPI and the Uzbek Cotton Breeding and Seed Production Institute identified selections with high fiber content, large bolls, early maturing, dwarf growth habit, low gossypol, and pigmented fiber (Visotskii, 1963). The Uzbek Cotton Breeding and Seed Production Institute independently manages a collection of about 12,000 Gossypium accessions (Saidaliev and Abdullaev, 1995).

Onion. Central Asiais reported to be the center of origin for onions, Allium sp., (Vavilov, 1951). In addition to $A$. cepa $\mathrm{L}$., many wild relatives are native to this region (A. oshaninii O. Fedtsch., A. vavilovii M. Pop. et Vved., A. praemixtum B. Fedtsch., and A. pskemense B. Fedtsch.). Over 110 wild Allium species exist within the Republic of Uzbekistan alone, with over 500 accessions held in the collection at the Uzbek Institute of Botany in Tashkent (Abdukarimov et. al, 1996). Breeders at UzRIPI developed the successful onion cultivar 'Dungamskii 12'.

Melons. Central Asia is reported to be the center of origin/diversity for melons (Vavilov, 1951). Konstantin I. Pangalo was primarily responsible for the collection and breeding of melons (Cucumis melo) and squashes ( $\mathrm{Cu}$ curbita pepo L., C. moschata Duch, and $C$. maxima Duch.) at the institute. As a result of many extensive collection expeditions, UzRIPI currently has a germplasm holding of approximately 1,600 melon accessions. Unique melon 
types were discovered in Khorazm province in the northern part of Uzbekistan that exhibit high organoleptic quality, high sugar content, and a long shelf life (Ermohin et al., 1962). In the 1950s, the successful melon cultivar 'Umirvaki 3748' (Fig. 2) was released by the institute and is still being grown today. Table 3 describes selected melon cultivars developed at the institute. Pangalo studied the Cucurbitaceae germplasm collection thoroughly and used his results to formulate a new classification system (Pangalo, 1950; Filov, 1960). An English version of the popular "Atlas of Uzbek Melons" by R.F. Mavlynova, R.A. Hakimov, and others will be published in 2005 .

Fruit and nuts. The institute's germplasm collection contains many unique and potentially valuable fruits and nuts. For example, the cherry-plum (Prunus cerasifera Ehrh.) has been collected from the western Tien Shan Mountains (Tsangas, 1994). Disease resistant and cold and frost tolerant apricot (Prunus armeniaca $\mathrm{L}$.) and apple (Malus $\times$ domestica Borkh.) selections were identified and collected from very old orchards throughoutCentral Asia. In the western
Kopetdag Mountain Range of Turkmenistan, a new species of fig (Ficus afghanistanica Warb.) has been discovered (Tsangas, 1994). Selections of Turkmenian cherry (Cerasus turcomanica Pojark.) have been collected as well as two botanical types of hawthorn (Crataegus pontica C. Koch. and C. necopinata Pojark).

Embryology and self-compatibility have been studied in peach [Prunus persica (L.) Batsch.] at the institute (Baimetov, 1988). Also, a new classification system of peach was proposed based on botanical/geographical methods originally developed by N. I. Vavilov. This system comprised five geographical regions: China, Europe, North America, Caucasus, and Central Asia. The Central Asian region was further divided into nine subgroups and the performance of cultivars from all of the groups were tested under Central Asian growing conditions (Baimetov, 1995).

Tree and small fruit breeding was started at the institute in the late 1920s. New cultivars were released as early as the 1930 s. Galina M. Popova worked with wild fruit species including plums (Prunus domestica L.) and apples, while Klavdiya F. Kostina collected and bred apricots. The following successful apricot, sweet cherry (Prunus avium L.), peach, and nectarine cultivars were developed and released by the institute: apricot 'Vimpel', 'Zaraya Vostoka', 'Komsomolets', 'Spitak kremovii', 'Hurmai rannii', and 'Oranjevii pozdnii 263' (Table 4); sweet cherry 'Valerii Chkalov' and 'Kosmicheskaya'; peach 'Rannii Belii VIRa', 'Gulnoz', 'Chimgan', 'Lyuchak', 'Zolotoi Ubilei', and nectarine 'Uchkun' (Table 5).

Accessions of Persian walnuts (Juglans regia), pistachios (Pistacia vera L.), and almonds [Prunus dulcis (Mill.) D.A.Webb.] are held in the collection. Four wild species of almonds are also included (Prunus bucharica Korsch., $P$. communis L., P. scoparia Spach., and $P$. spinosissima Franchet).

Wheat and barley. Since the 1920s, many different types of bread wheat (Triticum aestivum) and barley (Hordeum vulgare) have been collected, featuring traits such as early maturity, cold hardiness, drought tolerance, and salt tolerance. The collections of wheat from Tajikistan and Kyrgyzstan express very early maturity,

Table 3. Characteristics of selected melon cultivars developed at the institute.

\begin{tabular}{|c|c|c|c|c|c|}
\hline Name & $\begin{array}{l}\text { Total } \\
\text { sugar } \\
(\%)\end{array}$ & $\begin{array}{l}\text { Flesh } \\
\text { color }\end{array}$ & Shape & $\begin{array}{r}\text { Wt } \\
(\mathrm{kg})\end{array}$ & $\begin{array}{l}\text { Rind } \\
\text { type }\end{array}$ \\
\hline \multicolumn{6}{|l|}{ Early-Maturing (50-80 d) } \\
\hline \multicolumn{6}{|l|}{ Mid-Maturing (80-100 d) } \\
\hline Bosvald & $7.0-8.6$ & Light-green & Elliptical & $3.0-4.0$ & Striped \\
\hline Assate & Up to 10.0 & white & Ovate & $4.0-7.0$ & Netted \\
\hline Obinavot & $7.4-9.3$ & White & Round & $3.0-4.0$ & Spotted \\
\hline Arabakeshka 1219 Shakar palak & 10.0 & White & Ovate & $8.0-17.0$ & Netted \\
\hline Krasomysni 2580 & $9.0-11.0$ & Orange & Elliptical & $3.0-4.0$ & Netted \\
\hline Koi-bash 476 & $8.0-11.0$ & White & Ovate & $3.0-9.0$ & Netted \\
\hline \multicolumn{6}{|l|}{ Late-Maturing (100-130 d) } \\
\hline Gulybi Oranjevay & 9.5 & White & Ovate & $4.0-7.0$ & Lightly netted \\
\hline Umirvaki 3748 & Up to 10.5 & White-green & Ovate & $3.0-6.0$ & Lightly netted \\
\hline Kok Gulybi & $9.6-14.0$ & White & Ovate & $7.0-25.0$ & Wrinkle-netted \\
\hline
\end{tabular}

Table 4. Characteristics of selected apricot cultivars developed at the institute.

\begin{tabular}{|c|c|c|c|c|c|c|}
\hline Cultivar & $\begin{array}{c}\text { Avg } \\
\text { fruit } \\
\text { wt } \\
(g)\end{array}$ & $\begin{array}{l}\text { Fruit } \\
\text { color }\end{array}$ & $\begin{array}{c}\text { Years to } \\
\text { fruit } \\
\text { production }\end{array}$ & $\begin{array}{c}\text { Yield } \\
\left(\mathrm{t} \cdot \mathrm{ha}^{-1}\right)\end{array}$ & $\begin{array}{l}\text { Ripening } \\
\text { time }\end{array}$ & $\begin{array}{l}\text { Major } \\
\text { end } \\
\text { use }\end{array}$ \\
\hline Komsomolets & $75-80$ & Yellow-orange with carmine ruddiness & $4-5$ & $12-13$ & Mid-June & fresh \\
\hline \multirow[t]{2}{*}{ Vimpel } & $60-70$ & & & & & \\
\hline & Up to 105 & Yellow-carmine with carmine ruddiness & ss $3-4$ & $12-13$ & Early-June & Dried fresh and canned \\
\hline Zaraya Vostoka & $65-70$ & Light-yellow with bright pink ruddiness & ss 5 & $12-12.3$ & Late-June & Table, dried \\
\hline Spitak kremovii & $60-65$ & $\begin{array}{l}\text { Light green to cream with pink-carmine } \\
\text { ruddiness }\end{array}$ & ne 5 & $13-14$ & Late-June to early July & Table, canned \\
\hline Hurmai ranni & $30-35$ & Light green with orange, no ruddiness & $4-5$ & $13-13.5$ & Early-June & Table, dried \\
\hline Oranjevii pozdnii 263 & $30-35$ & Yellow-orange with dark red ruddiness & s $5-6$ & $14-15$ & Late-June to early July & Canned \\
\hline Gevandi & $40-50$ & Yellow-orange with red ruddiness & $5-6$ & $12-13$ & Early-June & Table, canned \\
\hline
\end{tabular}

Table 5. Characteristics of selected peach cultivars developed at the Institute.

\begin{tabular}{|c|c|c|c|c|c|c|}
\hline Cultivar & $\begin{array}{l}\text { Avg } \\
\text { fruit } \\
\mathrm{wt} \\
(\mathrm{g})\end{array}$ & $\begin{array}{l}\text { Fruit } \\
\text { color }\end{array}$ & $\begin{array}{l}\text { Years to } \\
\text { fruit } \\
\text { production }\end{array}$ & $\begin{array}{c}\text { Yield } \\
\left(\mathrm{t} \cdot \mathrm{ha}^{-1}\right)\end{array}$ & $\begin{array}{l}\text { Ripening } \\
\text { time }\end{array}$ & $\begin{array}{l}\text { Major } \\
\text { end } \\
\text { use }\end{array}$ \\
\hline Gulnoz & $130-150$ & Cream-white with ruddiness & 2 years & $18-20$ & Mid-June & Fresh \\
\hline Bellii Rannii VIRa & $100-150$ & Cream-white with carmine ruddiness & NA & NA & Late June & Fresh \\
\hline Chimgan & $90-100$ & Yellow no ruddiness & 2 years & $18-19$ & Late July, early August & Dried, fresh, and canned \\
\hline Uchkun (nectarine) & $110-120$ & Cream-yellow with ruddiness & 2 years & $16-17$ & Late July, early August & Fresh \\
\hline Lyuchak & $65-70$ & Yellow with light carmine & 2 years & $17-18$ & Late June, early July & Dried, fresh, and canned \\
\hline Elberta (U.S.-check) & $150-170$ & orange-yellow with carmine & 2 years & $17-18$ & Mid-August & Dried, fresh, and canned \\
\hline Jerseyland (U.S.-check) & $150-180$ & Dark orange with claret & 2 years & $18-20$ & Early July & Dried, fresh, and canned \\
\hline
\end{tabular}


compact growth habit, and inflated short glumes. These include varieties alborubraiflatum Vav., lutinfatum Flaksh., and eritrospermum inflatum Palm., where cold hardiness and salt tolerance is particularly notable. Forms of bread wheat were also discovered that lack ligules.

Roald A. Udachin discovered nine new wild relatives of bread wheat within the Central Asian collection (Udachin and Shahmedov, 1984). Cytogenetic studies of newly discovered wild relatives (Triticum sphaerococcum Perc., T. turanicum Jakubbz., $T$. persicum Vav., and $T$. jakubziheri Udazc. et Shachm.) are being conducted to determine phylogenetic relationships and to investigate their potential for interspecific hybridization with cultivated wheat (Kurbanov et al., 1988). The bread wheat cultivars 'Unumli Bugdai', 'Karlik 85', and 'Psevdomeridionali 122 ' and durum wheat cultivars 'Dobraya' and 'Aleksandrovka' have been developed and released based on germplasm collected and maintained at the institute. R.A. Udachin and I.Sh. Shahmedov published the monograph "Central Asian Wheats" in 1984. In addition to wheat, barley and triticale were bred at the institute developing an extremely early maturing barley 'Zafar' and the triticale cultivars 'Uzor', 'Prag serebristii', and 'Mnogozernii 2'. G.K. Kurbanov published a monograph on dryland barley in Uzbekistan in 1972.

Maize. New drought and heat tolerant cultivars of maize (Zea mays) have been released by the institute. Scientists at the institute developed effective field evaluation methods using a drought tolerance scoring system that includes five categories $(1=$ drought tolerant, $5=$ drought intolerant) to screen maize populations (Gorbunov, 1977, 1991). Accessions from Asia, Africa, North America, and South America are being grown under varying levels of field moisture and are scored for drought tolerance. Cytoplasmic male sterility (CMS, Moldavian type) has also been used to assist in the production of hybrid seed (Massino et al., 2000).

Fiber crops. Breeding programs have been conducted in fiber crops, including jute (Corchorus olitorius L). Nikolai V. Kultiasov and Grigorii A. Pereverzev were awarded with the highest State Prize in the former Soviet Union for the development of the jute 'Pervenets Uzbekistana 420 '. It has an average fiber content of $21 \%$, plant height of 2 to $2.5 \mathrm{~m}$, yield of 10 $\mathrm{t} \cdot \mathrm{ha}^{-1}$ (dry mass), and it is resistant to prevalent diseases.

Strawberry. In 1945, an extensive strawberry (Fragaria spp.) collection and breeding program was initiated at the institute. Since then, 14 cultivars were released including 'Maiskii', 'Tashkentskaya', 'Yujanka', 'Yutuk', 'Yulduz', 'Yunost', 'Syurpriz', 'VIRa', 'Slava Trudu', 'Saule', 'Sevara', and others.

Vegetables. Systematic vegetable breeding was initiated at the institute in 1928. Improved cultivars of tomato 'Kellred' and 'Chudo rinka'; pepper (Capsicum annuum L.) 'Gloriya'; eggplant 'Sentsaciya'; and carrot 'Murzoi krasnaya 542' were developed and released during the 1930s and 1940s. In the 1950s the tomatoes 'Maikopskii urojainii 2090' and 'Temnokrasnii 2077' were released and are still being grown today. Since then, the institute released many successful vegetable cultivars including the tomatoes 'Vostok 36', 'Oktyabr', 'Ravshan 40', 'Uzbekistan', and 'Progressivnii'; an extremely early maturing garlic (A. sativum L.) 'Maiskii VIR'; dill 'Uzbekskii 243' and 'Orom'; pepper 'Dar Tashkenta'; eggplant 'Avrora'; lettuce 'Kuk shokh'; and radish 'Kuz khadaysi'.

Cultivars of other species developed at the institute include castor bean (Ricunus microcarpus ssp. sanguineus. Pop.) 'Tashkentskii 351'; peanut (Arachis hypogaea ssp. vulgaris) 'Tashkentskii 112'; sesame (Sesamum indicum L.) 'Tashkentskii 122'; safflower (Carthamus tinctorius L.) 'Tashkentskii 51'; and mung bean 'Pobeda 104'.

\section{Conclusions}

The Uzbek Research Institute of Plant Industry acts as a comprehensive scientific research institution in addition to maintaining and continually enhancing a vast germplasm repository representing numerous valuable plant species. Since its establishment in 1924, the institute has been actively engaged in plant exploration, collection, research, evaluation, and genetic improvement. Current germplasm holdings, research, and breeding efforts are described in this paper to familiarize scientists in the western world with the greatly underutilized assets of the institute. UzRIPIlooks forward to collaboration, cooperation, and reciprocal exchange of plant germplasm with interested scientists and organizations around the world.

\section{Literature Cited}

Abdukarimov, A.A., A.A. Ashurmetov, and I.V. Belolipov. 1996. Uzbekistan: country report to the FAO international technical conference on plant genetic resources. Leipzig, Tashkent.

Baimetov, K.I. 1988. Study of peach self-compatibility (in Russian). Proceedings of the All Union N.I. Vavilov Inst. Plant Ind. 119:78-84.

Baimetov, K.I. 1995. Characteristics of North American peach cultivars, p. 111-117. In: O.E. Shiryaeva (ed.). Central Asian plant resources for plant breeding (in Russian). Uzinformagroprom. Tashkent.

Brejnev, D.D. 1974. Central Asia-Gene center of cultivated plants and it significance for plant breeding(in Russian). VIR Leningrad. 9:3-8.

Ermohin, V.N., A. Karimov, E.V. Uspenskaya, and P.N. Dudko. 1962. Atlas of Uzbek Melons (in Russian). Gosizdatelstvo Uzbek S.S.R., Tashkent.

Esenbaev, Z.I., R.A Safarov, N.G. Gaibov, M.M. Mirzaev, M.M., and M.M. Penson. 1981. Orchards of Uzbekistan (in Russian, Uzbek, and English). Uzbekistan. Tashkent. Filov, A.I. 1960. Melon systematic. Agriculture Science. Moscow. 1:26-132.

Gorbunov, V.P. 1977. Evaluation of maize inbreds for drought tolerance and response to irrigation. p. 270. In: S.G. Galeeva and G.E. Shmaraeva (eds.). Catalogue of World Collection (in Russian). vol. 213. All Union N.I. Vavilov Inst. Plant Ind., Leningrad.

Gorbunov, V.P. 1991. Methods for the field evaluation of maize cultivars for drought tolerance, $p$. 4. In: N.S. Polishuk (ed.). Info. Publ. Innovative Methods (in Russian). UzNIINTI, Tashkent.

Juravel, M.S. and N.G. Ruban. 1968. Studies of parental combinations for breeding earliness in grapes, p. 123-133. In: L.E. Ionova (ed.). World Plant Collection for Central Asian Agr. (in Rus- sian). Fan, Tashkent.

Kim, U.M. and T.K. Duisenov. 1994. Cultivation of Stevia sp. in irrigated regions of Uzbekistan, $\mathrm{p}$. 109-112. In: O.E. Shiryeva (ed.). Plant resources of Central Asia for breeding (in Russian). Uzinformagroprom, Tashkent.

Kurbanov, G.K. 1972. Barley in unirrigated lands in Uzbekistan (in Russian). Fan, Tashkent.

Kurbanov, G.K., I. Sh. Shahmedov, and A.C. Abdulvahid. 1988. Interspecific hybridization $T$. persicum with others Triticum species, p. 15-23. In:A. Tairov (ed.). Use of the world collections for creating new intensive field crops in Uzbekistan (in Russian). Uzgiprozem, Tashkent.

Levkina,L.V. 1992. The use of cold storage conditions for seeds, p. 80-85. In: D.U. Akhujanova (ed.). The use of world plant collection in the Central Asian region (in Russian). Uzinformagroprom, Tashkent.

Massino, I., M. Mavrin, and S. Ahmedova. 2000. Studies of maize in Uzbekistan, p. 176-178. In: G. Srinivasan and M. Karabaev (eds.). Proceedings of an International Workshop: Maize Production and Improvement in Central Asia and the Caucasus (in Russian.). Kazakhstan-Kyrgyzstan, Bishkek.

Mavlyanova, R.F., O.F. Polyanichko, T. Holmuninov, and R. Salaev. 1998. Selection for desirable traits in root crops. Proceedings of the Uzbek National Academy of Science (in Russian). Tashkent 4:35-37.

Pangalo, K.I. 1950. Melons as an independent genus. Bot. J. (in Russian). Moscow 35(6):571-580.

Pugachev, I.I. and H.D. Djabbarov. 1974. Central Asian Branch of VIR-50th anniversary (in Russian). VIR, Leningrad 46:9-15.

Ruban, N.G. 1972. Grape cultivars of Central Asia (in Russian). Fan, Tashkent.

Saidaliev, H. and A. Abdullaev. 1995. Using the world cotton germplasm collection for breeding purposes, p. 26-34. In: T. Pardaev and D. Ahunganova (eds.). Genetics, breeding, and seed production of cotton and alfalfa (in Russian). Uzinformagropom, Tashkent.

Shahmedov, G.S. and N.K. Lemeshev. 1987. Breeding of cotton forms with different ploidy levels and its cytological and genetic peculiarities, p. 9-15I. In: V.F. Dorofeev (ed.). Scientific proceedings of applied botany, genetics and breeding (in Russian). vol 113. VIR, Leningrad.

Tsangas, F.T. 1994. Germplasm collection in Central Asia, p. 7-15. In: O.E. Shiryaeva (ed.). Plant resources of Central Asia for breeding (in Russian). Uzinformagroprom, Tashkent.

Udachin, R.A. and I.S. Shahmedov. 1984. Wheat of Central Asia (in Russian). p.135. Fan, Tashkent.

Vavilov, N.I. 1926. Centers of origins of cultivated plants. Scientific proceedings of applied botany, genetics and breeding (in Russian). VIR 116(2):248.

Vavilov, N.I. 1951. The origin, variation, immunity, and breeding of cultivated plants. In: F. Verdoorn (ed.). K. Starr Chester (translator). Chronica Bot. (13) $1 / 6$.

Visotskii, K.A. 1963. Heterosis of cotton, p. 9-16. Scientific proceedings of the Central Asian station of the All-Union Institute of Plant Industry (in Russian). Uzglavizdat, Tashkent.

Visotskii, K.A. 1968. Interspecific hybridization in the Malvaceae family and cotton heterosis, $\mathrm{p}$. 177-198. In: S.G. Tarakanov (ed.). VIR world collection and benefits for Central Asia (in Russian). Fan, Tashkent.

Zaitcev V.I., L.V. Levkina, and R.F. Mavlyanova. 1993. Influence of super-low temperatures on carrot seed parameters and plant morphology, p. 58-59. In: V.I. Kravchenko (ed.). Study of the gene pools of cultivated plants and related species in Central Asia. Sci.-Tech. Bul. VIR (in Russian). vol. 232. 